Revista Eletrônica Geografar, Curitiba, v. 2, Resumos do VI Seminário Interno de Pós-Graduação em Geografia, p. 30-30. Junho/2007

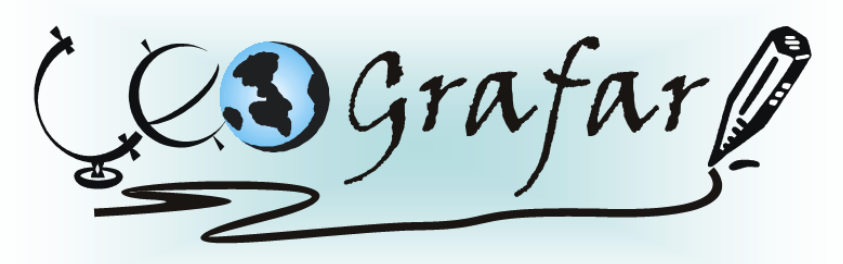

Revista Eletrônica do Programa de Pós-Graduação em Geografia - UFPR

\title{
CARACTERIZAÇÃO DA PAISAGEM CÁRSTICA DO PARQUE ESTADUAL DE CAMPINHOS
}

\section{FRANCISCO CARLOS REHME ${ }^{1}$}

A ação da água, por meio do intemperismo químico associado à força mecânica, dissolve e, ao mesmo tempo, esculpe a rocha calcária, num processo erosivo e acumulativo contínuo e de longo curso. Dessa dinâmica resultam formações subterrâneas, como as cavernas e abismos e feições de superfície, como os lapiás e as dolinas, que constituem a paisagem cárstica, e em virtude de suas peculiaridades geológicas, geomorfológicas e inter-relações ecossistêmicas, são aspectos relevantes para a investigação científica. Inserido neste contexto, o Parque Estadual de Campinhos, situado na porção setentrional do primeiro planalto, criado para proteção e visitação racional de seus diversos atrativos, sobretudo do Sistema Jesuítas - Fada, conjunto composto por duas de suas principais cavernas, é objeto desta pesquisa. A análise preliminar da disposição dos níveis de encavernamento desse sistema e a presença de uma dolina de colapso a ele associado, sugerem o processo evolutivo do carste local, deste modo busca-se nesta investigação coletar elementos que possibilitem uma melhor compreensão de seu paleo-ambiente, como à projeção dos próximos estágios de evolução morfológica. Em 2003, entrou em vigor o Plano de Manejo do Parque Estadual de Campinhos, propondo modificações em sua infra-estrutura de visitação, recuperando trilhas e definindo, entre outros aspectos, os locais e percursos destinados à exploração turística, além de revisar o limite de visitantes por dia e por incursão. Deste modo, o estudo ao desenvolver o conhecimento na caracterização das formas cársticas que valorizam o Parque Estadual de Campinhos; seja sob o aspecto turístico ou, da educação ambiental; na pesquisa científica, permitirá contribuir para o reconhecimento de áreas de entorno neste carste como uma área de grande potencial, para a investigação da dinâmica natural desta paisagem e contribui para a própria avaliação das mudanças paisagísticas já resultantes de ações desencadeadas pelo cumprimento da normatização do Plano de Manejo em vigor.

Palavras-chave: Morfogênese do Carste - Paleo-ambiente - Plano de Manejo

${ }^{1}$ Mestrando em Geografia - UFPR - email:chicho@colegiomedianeira.g12.br Orientador: EVERTON PASSOS 